\title{
Estrogen receptor-associated receptor $\alpha$ and peroxisome proliferator-activated receptor $\gamma$ in metabolism and disease (Review)
}

\author{
WEI-YI HUANG and PENG-MING SUN \\ Laboratory of Gynecologic Oncology, Fujian Provincial Maternity and Children's Hospital, \\ Affiliated Hospital of Fujian Medical University, Fuzhou, Fujian 350001, P.R. China
}

Received April 19, 2020; Accepted October 13, 2020

DOI: $10.3892 / \mathrm{mmr} .2020 .11795$

\begin{abstract}
Estrogen receptor-associated receptor $\alpha(E R R \alpha)$ is an orphan nuclear receptor that lacks corresponding ligands. ERR $\alpha$ recruits co-regulators to regulate gene transcription and plays an important role in human physiological functions. Peroxisome proliferator-activated receptor $\gamma(\operatorname{PPAR} \gamma)$ is also a nuclear receptor that regulates the expression of target genes via a ligand-dependent mechanism, thereby participating in a series of physiological processes. Both ERR $\alpha$ and PPAR $\gamma$ are involved in the process of energy metabolism and tumorigenesis. In the present review, a concise overview of the important roles governed by ERR $\alpha$ and PPAR $\gamma$ in metabolism and their association with various disease are provided.
\end{abstract}

\section{Contents}

1. Introduction

2. Distribution and function of ERR $\alpha$ and PPAR $\gamma$

3. Association of ERR $\alpha$ and PPAR $\gamma$ with disease

4. Conclusions and perspectives

\section{Introduction}

Estrogen receptor-associated receptor (ERR) is an orphan nuclear receptor that exerts its biological function without binding to a ligand. In 1988, Giguère et al (1) identified a nuclear receptor that was highly homologous with ER $\alpha$ in nucleotide and amino acid sequences using cDNA for the DNA-binding domain of estrogen receptor $\alpha(\mathrm{ER} \alpha)$ as the probe. Both ERR and ER are type III nuclear recep-

Correspondence to: Professor Peng-Ming Sun, Laboratory of Gynecologic Oncology, Fujian Provincial Maternity and Children's Hospital, Affiliated Hospital of Fujian Medical University, 18 Daoshan Road, Fuzhou, Fujian 350001, P.R. China

E-mail: fmsun1975@fjmu.edu.cn

Key words: estrogen receptor-associated receptor $\alpha$, peroxisome proliferator-activated receptor $\gamma$, metabolism, disease, tumorigenesis tors. To date, the following three subtypes have been found, ERR $\alpha$ (NR3B1), ERR $\beta$ (NR3B2) and ERR $\gamma$ (NR3B3), in which ERR $\alpha$ is widely distributed in various adult tissues and participates in a variety of physiological processes, including mitochondrial biogenesis (2), gluconeogenesis, oxidative phosphorylation (3), fatty acid metabolism (4) and brown adipose tissue thermogenesis (5). It was also identified as an important regulator of the mammalian circadian clock, and its output pathways at both transcriptional and physiological levels regulated the expression of transcription factors involved in metabolic homeostasis (6). The ERR $\alpha$-encoding gene is located at site 11q13 of the human chromosome and primarily consists of the following three functional domains: $\mathrm{N}$ terminal domain (NTD), DNA-binding domain (DBD) and ligand binding domain (LBD). Activation function 1 (AF1) is located at the NTD, while AF2 is located at the LBD (7). The DBD of ERR $\alpha$ contains two zinc fingers, which are used for identification and binding of special sequences at the regulatory region in the DNA of the target gene (8). AF2 regulates the transcriptional activity of nuclear receptors, primarily through functional interactions with coactivators, such as peroxisome proliferator-activated receptor $\gamma$ coactivator-1 (PGC-1), or corepressors, such as nuclear factor RIP140 (8).

Peroxisome proliferator-activated receptor (PPAR) is a novel steroid hormone receptor discovered by Issemann and Green (9) in 1990, which can be activated by fatty acid-like peroxisome proliferator. PPARs are nuclear transcription factors activated by ligands and members of the type II nuclear hormone receptor superfamily. There are three subtypes of PPARs: PPAR $\alpha, \beta / \delta$ and $\gamma(10)$. Typically, PPARs and retinoid $\mathrm{X}$ receptors (RXR) form a heterodimer and recruit a co-inhibitory protein complex to inhibit the transcription of target genes (10). When PPARs are combined with ligands and activated, this heterodimer may release co-inhibitor proteins and bind to coactivator proteins, and subsequently combine with the promoter of the target gene, upstream peroxisome proliferator response element (PPRE), to regulate its transcription and activate its biological function (10). The PPAR $\gamma$ gene is located in the p25 region of chromosome 3 and contains six regions known as regions $\mathrm{A}-\mathrm{F}$, which are divided into four functional domains: Amino terminal domain, DNA binding domain, transcriptional activity regulatory domain and ligand 
binding domain (11). PPAR $\gamma$ regulates gene transcription through binding of the DNA binding domain to PPRE, and a number of nuclear factors, such as protein kinase $\mathrm{C}$, protein kinase A and 5'AMP-activated protein kinase can affect the activity of PPAR $\gamma$ after binding to this domain $(12,13)$.

\section{Distribution and function of ERR $\alpha$ and PPAR $\gamma$}

ERR $\alpha$ is expressed in a variety of tissues from embryonic development to adulthood. The expression of ERR $\alpha$ can be detected in the heart, brain, kidney, brown adipose tissue (BAT), intestines, bones and uterus (Table I) (14). The expression of ERR $\alpha$ is higher in metabolically active tissues, including the heart, white adipose tissue, BAT and macrophages, while it is relatively lower in the liver, lung and vagina $(15,16)$. Studies have demonstrated that ERRs play an important role in the regulation of eukaryotic gene expression, embryonic development, cell proliferation, bone cell production and angiogenesis (17-19). ERR $\alpha$ is an orphan nuclear receptor that does not have corresponding ligands, but may interact with and have a bypass effect on the classical oestrogen signalling pathway through competitive binding to the same target genes, transcription factors and coactivator proteins with $\operatorname{ER} \alpha(7,20,21)$. Earlier studies reported the important role of ERR $\alpha$ in energy metabolism of the body via the regulation of its target genes. The metabolic processes that ERR $\alpha$ plays a role in include glucose metabolism $(22,23)$, lipid metabolism (24) and mitochondrial oxidation metabolism (25-27). ERR $\alpha$ regulates the process of glucose metabolism mainly by affecting the gluconeogenic pathway and the derivatization of mitochondria $(28,29)$. ERR $\alpha$ influences the lipid metabolism process through targeting and regulating genes of the fatty acid $\beta$ oxidation pathway, such as acetyl-coenzyme A dehydrogenase and malonyl coenzyme A decarboxylase (30). ERR $\alpha$ regulates mitochondrial oxidation metabolism by upregulating gene expression related to oxidative phosphorylation through combined action with PGC-1 $\alpha$ as the coactivator (31). When the body is affected by changes in the external environment, such as hunger and cold temperatures, the upregulation of ERR $\alpha$ expression may promote energy generation and the utilization of body energy, achieving an optimal adaptive state (32).

The mRNA of PPAR $\gamma$ is made up of $\sim 4,000$ nucleotides. A total of four subtypes of mRNA can be produced by different promoters and alternative splicing: PPAR $\gamma 1, \operatorname{PPAR} \gamma 2, \operatorname{PPAR} \gamma 3$ and PPAR $\gamma 4$ (33). The isomers of these four mRNA subtypes have different promoters, expression modes, ligand affinity and tissue distribution. PPAR $\gamma 1$ is the main subtype of PPAR $\gamma$ and is relatively widely distributed (34). It is primarily distributed in adipose tissue, liver, heart, pancreas, intestines, kidney and skeletal muscle. The expression levels of PPAR $\gamma 2$ are the highest in adipose tissue, and lowest in skeletal muscle (35). PPAR $\gamma 3$ is expressed only in macrophages and the large intestine (36). However, little is known concerning PPAR $\gamma 4$ expression. PPAR $\gamma$ is differently expressed in a variety of tissues (Table I) (14). PPAR $\gamma$ regulates the expression of target genes through ligand-dependent mechanisms, thereby participating in a series of physiological processes. There are two types of PPAR $\gamma$ ligands: Endogenous and exogenous (37). The exogenous ligands contain insulin sensitizers used in the treatment of clinical diabetes, tyrosine-containing drugs, such as GW1929, and phenylacetic acid derivatives, such as ibuprofen (38). The endogenous ligands are mainly prostaglandin-derived metabolites (39). PPAR $\gamma$ forms a heterodimer with RXR $\alpha$, and then binds to a specific DNA sequence of the PPRE to activate target genes (40). Based on previous studies, PPAR $\gamma$ exerts various biological effects and plays important roles in lipid metabolism (41), glucose metabolism (42), atherosclerosis formation (43) and inflammatory response (44). In addition, as a nuclear hormone receptor, PPAR $\gamma$ can affect the function of fatty acids and its derivatives at the transcriptional level to regulate cell survival and control the occurrence and development of cancer in different tissues (45).

Both ERR $\alpha$ and PPAR $\gamma$ are members of the nuclear receptor superfamily, and as ligand-dependent transcription factors, they need to bind to co-factors to form heterodimers and participate in the regulation of their target genes. A genome-wide analysis of ERR $\alpha$ and ERR $\gamma$ has confirmed their direct and overlapping binding at the promoter regions of a large number of mitochondrial genes, a number of which are PGC-1 $\alpha$ targets (46). These genes cover various aspects of mitochondrial oxidative metabolism, ranging from glucose utilization, fatty acid oxidation, the tricarboxylic acid (TCA) cycle and oxidative phosphorylation (OXPHOS) (46). Using laser capture techniques, Teng et al (47) demonstrated that the expression of the selected ERR $\alpha$ target gene isocitrate dehydrogenase (IDH) was involved in the TCA cycle. PPAR $\gamma$ is a master regulator of macrophage polarization. Angajala et al (48) showed that macrophages control the first break of the TCA cycle that occurs in the enzymatic step involving IDH. Wei et al (49) demonstrated that rosiglitazone-activated PPAR $\gamma$ can induce ERR $\alpha$ expression. PGC-1 $\alpha$ can target ERR $\alpha$ and transactivate nuclear factor erythroid 2-related factor (NRF)1/NRF2 target genes, which are the nuclear respiratory factors (50). In addition, research has revealed that the induction of NRF1 transcription factors is a prerequisite for the transcriptional activation of cytochrome $c$ (cyt $c$ ), which is an important electron transporter in OXPHOS (51). ERR $\alpha$ was previously implicated in regulating the gene encoding medium-chain acyl-CoA dehydrogenase (MCAD), which catalyses the initial step in mitochondrial fatty acid oxidation (52). Additionally, MCAD was previously reported to be a target gene of PPAR $\gamma$ (53). Gandhi et al (54) demonstrated that increased PPAR $\gamma$ levels can regulate insulin-mediated glucose uptake through the translocation and activation of glucose transporter type 4 in the PI3K/phosphorylated-Akt signalling cascade. Therefore, both ERR $\alpha$ and PPAR $\gamma$ can regulate the amount of acetyl-CoA that will enter the TCA cycle by affecting fatty acid metabolism. The aforementioned findings indicated that PPAR $\gamma$ can also affect the production of pyruvates associated with the TCA cycle by affecting the glycolysis pathway. It was also suggested that ERR $\alpha$ expression can influence cyt $c$ expression, which is closely associated with the OXPHOS process. Glycolysis, fatty acid metabolism, OXPHOS and the TCA cycle are all ubiquitous metabolic pathways in the body that provide the most direct energy source, ATP (Fig. 1).

\section{Association of ERR $\alpha$ and PPAR $\gamma$ with disease}

ERR $\alpha$ recruits co-regulators, is activated in a constitutive manner, regulates gene transcription, and serves an important 
Table I. Expression levels of ERR $\alpha$ and PPAR $\gamma$ in various tissues.

Gene

Top ten tissues of gene expression in C57/B16J mouse, displayed from high to low (14)

\begin{tabular}{lcccccccccc}
\hline ERR $\alpha$ & Jejunum & Ileum & $\begin{array}{c}\text { Olfactory } \\
\text { bulb }\end{array}$ & Kidney & Heart & $\begin{array}{c}\text { Gall } \\
\text { bladder }\end{array}$ & Muscle & $\begin{array}{c}\text { Preputial } \\
\text { gland }\end{array}$ & BAT & Duodenum \\
PPAR $\gamma$ & WAT & BAT & $\begin{array}{c}\text { Colon } \\
\text { Plomach }\end{array}$ & Preputial gland & Thyroid & Aorta & Skin & Ovary & Eye \\
\hline
\end{tabular}

ERR $\alpha$, estrogen receptor-associated receptor $\alpha$; PPAR $\gamma$, peroxisome proliferator-activated receptor $\gamma$; WAT, white adipose tissue; BAT, brown adipose tissue.

Table II. ERR $\alpha$-associated diseases and related tissues.

\begin{tabular}{ll}
\hline Tissue & \multicolumn{1}{c}{ Diseases (8) } \\
\hline Heart & $\begin{array}{l}\text { Ventricular hypertrophy, myocardial } \\
\text { infarction and heart failure } \\
\text { Obesity }\end{array}$ \\
WAT & $\begin{array}{l}\text { Diabetes and non-alcoholic fatty } \\
\text { Liver and } \\
\text { muscle }\end{array}$ \\
Bone & Osteoporosis disease \\
Human reproductive & Cancer \\
organs & \\
\hline
\end{tabular}

ERR $\alpha$, estrogen receptor-associated receptor $\alpha$; WAT, white adipose tissue.

role in cell physiological functions, as well as participates in the pathological processes of some diseases, such as diabetes, fatty liver and hepatocellular carcinoma (55). Research has demonstrated that the expression levels of OXPHOS-associated genes are downregulated early in the development of insulin resistance in human diabetes (56). ERR $\alpha$ is a target gene of PGC-1, and hence can regulate the expression of OXPHOS and fatty acid oxidation genes. Studies have reported that the expression levels of ERR $\alpha$-regulated genes are decreased in patients with insulin resistance (57), and there is an association between insulin sensitivity and the expression of ERR $\alpha$ mRNA in human adipose tissue (58). Overaccumulation of triglycerides in liver cells leads to non-alcoholic fatty liver disease (NAFLD). Decreased expression of ERR $\alpha$ affects the intake of dietary fat, thus inhibiting NAFLD development (59). In addition, a previous study indicated that the absence of ERR $\alpha$ activity promoted the development of rapamycin-induced NAFLD (60). Furthermore, in a mouse model of pressure overload-induced left ventricular hypertrophy, ERR $\alpha$ expression was found to be significantly downregulated, which resulted in faster development of heart failure (61). In addition, several studies found that in rodent models of heart failure, including models of decompensated right ventricular hypertrophy and myocardial infarction, and genetic models that show accelerated heart failure, the expression of ERR $\alpha$ and its coactivator are reduced (62-64).

A number of studies have demonstrated the close association between ERR $\alpha$ and the occurrence, development and clinical prognosis of various tumours. In hormone-dependent tumours, such as endometrial (65), ovarian (20), breast (66) and prostate cancer (67), ERR $\alpha$ may regulate tumour development through its effect on the ER $\alpha$ signalling pathway. In non-hormone-dependent tumours, including colorectal cancer, non-small cell lung cancer, nasopharyngeal carcinoma and glioma, ERR $\alpha$ may play a role by indirectly affecting gene transcription or proliferation of tumour cells. In endometrial cancer, a previous study revealed that upregulated expression of ERR $\alpha$ was significantly associated with tumour cell proliferation (68). Based on the findings of previous studies, it has been proposed that ERRs and ERs are co-expressed in ovarian cancer, and the interaction between these two families may be the molecular basis for the complex endocrine biological behaviour of ovarian cancer. Sun et al (20) showed that the ERR $\alpha$ was associated with the occurrence of ovarian cancer and the survival rate of patients, and could be used as a factor for poor prognosis of ovarian cancer. In addition, breast cancer is also a hormone-dependent tumour. Kraus et al (69) pointed out that ERR $\alpha$ could compete with ER $\alpha$ to bind to the oestrogen response element to regulate the transcription of target genes. Recent in vitro studies demonstrated that ERR $\alpha$ promoted triple-negative breast cancer (TNBC) cell migration and invasion, which was regulated by STAT3, providing a potential therapeutic option against TNBC metastasis (70). Previous studies on prostate cancer revealed that ERR protein was highly expressed in prostatic epithelial cells, whereas in prostate cancer cells expression was lower, and the increase of ERR $\alpha$ expression levels was significantly associated with prostate cancer development, disease prognosis and the survival rate of patients $(67,71)$. ERR $\alpha$-associated diseases and related tissues are shown in Table II (8).

The biological functions of PPAR $\gamma$ are complex and diverse, and studies have provided a number of novel approaches for the clinical prevention and treatment of diabetes (72), atherosclerosis, hypertension, NFLAD (73) and kidney disease (74). For the treatment of diabetes, thiazolidinedione (TZD) drugs can promote glucose utilization in skeletal muscle and inhibit glucose synthesis in the liver (75). When activated by TZD, PPAR $\gamma$ can promote the expression of the PI3K subunit $\mathrm{p} 85$, promote $\mathrm{c}-\mathrm{Cbl}$ associated protein (CAP) transcription, promote insulin signalling and improve insulin resistance (76). In islet $\alpha$ cells, activated PPAR $\gamma$ improved insulin resistance by suppressing the activity of the transcription factor Pax6 and suppressing the expression of glucagon at the transcription level (77). Studies have reported that PPAR $\gamma$ ligands can induce CD36 expression, promote the phagocytosis of oxidized low-density lipoprotein by macrophages and cause 


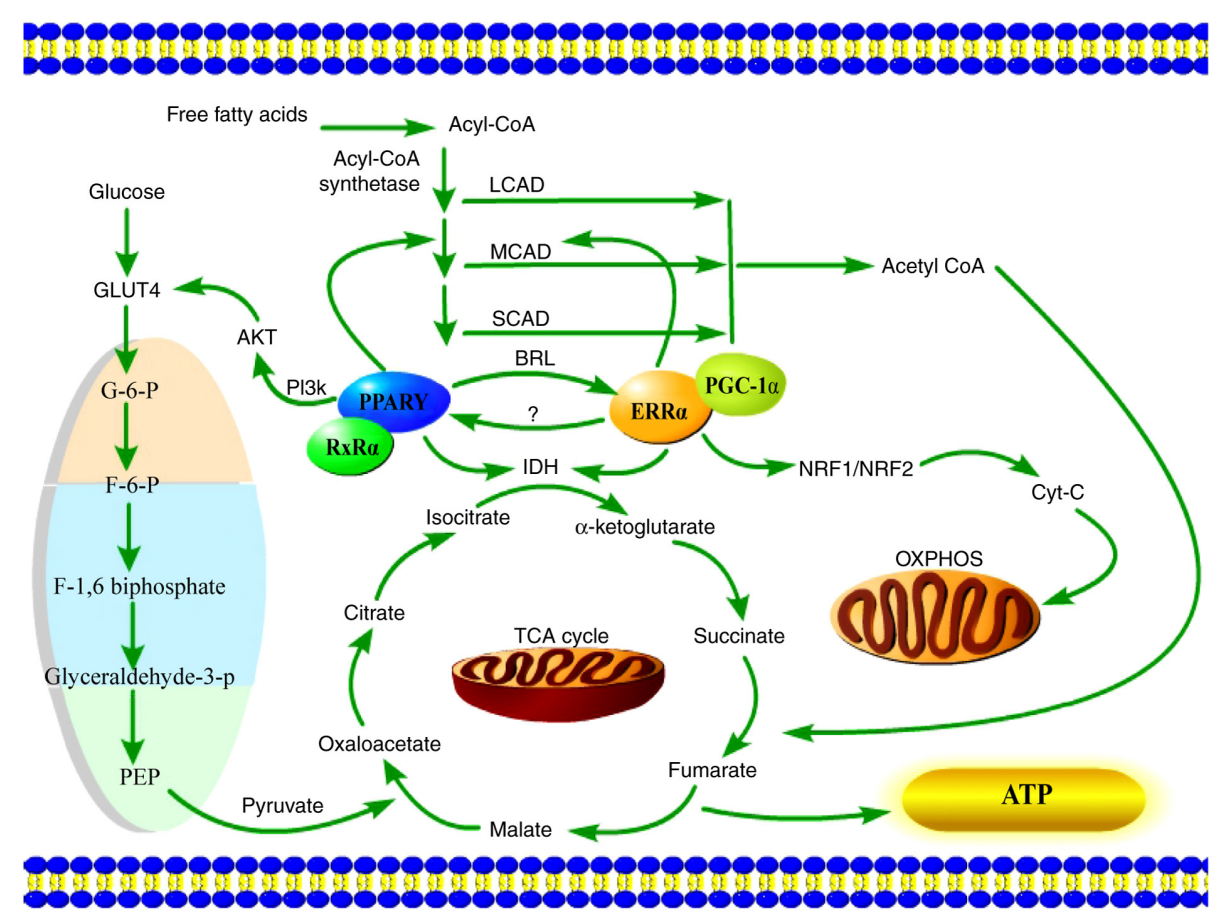

Figure 1. ERR $\alpha$ and PPAR $\gamma$ in energy metabolism. PPAR $\gamma$ affects glycolysis via the PI3K/p-Akt signaling pathway. Pyruvate produced by glycolysis enters the mitochondria to produce ATP via the TCA cycle. ERR $\alpha$ affects fatty acid oxidation via regulating MCAD and also affects OXPHOS via targeting NRF1/NRF2 genes. Acetyl CoA is produced through the $\beta$-oxidation of acyl-CoA and participates in the TCA cycle to produce ATP. The mitochondrial respiratory chain couples with ATP synthase to complete the process of OXPHOS and produce ATP. LCAD, long-chain acyl-CoA dehydrogenase; MCAD, medium-chain acyl-CoA; SCAD, short-chain acyl-CoA dehydrogenase; TCA, tricarboxylic acid cycle; OXPHOS, oxidative phosphorylation; ATP, adenosine triphosphate; ERR $\alpha$, estrogen receptor-associated receptor $\alpha$; PPAR $\gamma$, peroxisome proliferator-activated receptor $\gamma$; GLUT4, glucose transporter type 4; G-6-P, glucose 6-phosphate; F-6-P, fructose 6-phosphate; PEP, phosphoenolpyruvate; RXR $\alpha$, retinoid X receptor $\alpha$; PGC-1 $\alpha$, peroxisome proliferator-activated receptor $\gamma$ coactivator-1 $\alpha$; NRF, nuclear factor erythroid 2-related factor; cyt c, cytochrome $c$; IDH, isocitrate dehydrogenase.

Table III. PPAR $\gamma$-associated diseases and related tissues.

Tissue Diseases (96)

\begin{tabular}{ll}
\hline WAT & Diabetes and atherosclerosis \\
CNS & $\begin{array}{l}\text { Parkinson's disease, Alzheimer's disease, } \\
\text { brain injury and ALS } \\
\text { Heart }\end{array}$ \\
Kidney & Kardiomyopathies \\
Breast & Breast cancer
\end{tabular}

PPAR $\gamma$, peroxisome proliferator-activated receptor $\gamma$; WAT, white adipose tissue; CNS, central nervous system; ALS, amyotrophic lateral sclerosis.

intracellular lipid accumulation $(78,79)$. In addition to enabling lipids to be taken up by macrophages, PPAR $\gamma$ can also transfer excess intracellular cholesterol to the extracellular space via ATP-binding cassette transporter A1 protein (80). Intimal macrophages engulf cholesterol and form foam cells during the progression of atherosclerosis. PPAR $\gamma$ is expressed in the vascular endothelium, and PPAR $\gamma$ agonists can lower blood pressure (81). In vitro endothelial cell culture experiments found that TZD-like ligands can significantly promote the secretion of vasomotor factor C-type natriuretic peptide in bovine carotid artery endothelial cells and inhibit the secretion of the vasoconstrictor factor endothelin (82).
PPAR $\gamma$ is a nuclear hormone receptor and its transcriptional level may affect the oxidation of fatty acids and the mitochondrial biogenesis of BAT (83). Therefore, PPAR $\gamma$ is most likely involved in the development of cancer in different tissues by regulating cell proliferation and differentiation. The expression of PPAR $\gamma$ has been reported in various types of tumour cells, including breast (84), prostate (85) and lung cancer cells (86), and it has been found that the binding of PPAR $\gamma$ to its ligand could inhibit the growth of tumour cells (87). However, other studies found that the expression levels of PPAR $\gamma$ was significantly increased in endometrial (88) and epithelial ovarian cancer $(89,90)$. Dong (84) found that efatutazone, a PPAR $\gamma$ agonist, could promote the differentiation of tumour cells in breast cancer in a specific stage, and thus interfere with tumour occurrence and development. In a study on ovarian cancer, Luo et al (91) found that PPAR $\gamma$ could upregulate the expression levels of microRNA-125, and thereby inhibit the proliferation of ovarian cancer cells. In colon cancer, studies demonstrated that patients with high PPAR $\gamma$ expression were more likely to survive than those with low PPAR $\gamma$ expression (92). In lung cancer, PPAR activation may inhibit the metastasis of tumour cells by inhibiting the epithelium-mesenchymal transition (93). In pancreatic cancer, it was revealed that PPAR $\gamma$ was highly expressed in pancreatic cancer cells, and activation of PPAR $\gamma$ may inhibit the growth of PANC-1 cells (94). In gastric cancer, He et al (95) reported that rosiglitazone, a PPAR $\gamma$ agonist, could induce cell apoptosis, and thus inhibit the growth and invasion of tumour cells, and this effect could be reversed by GW9662, a PPAR $\gamma$ 


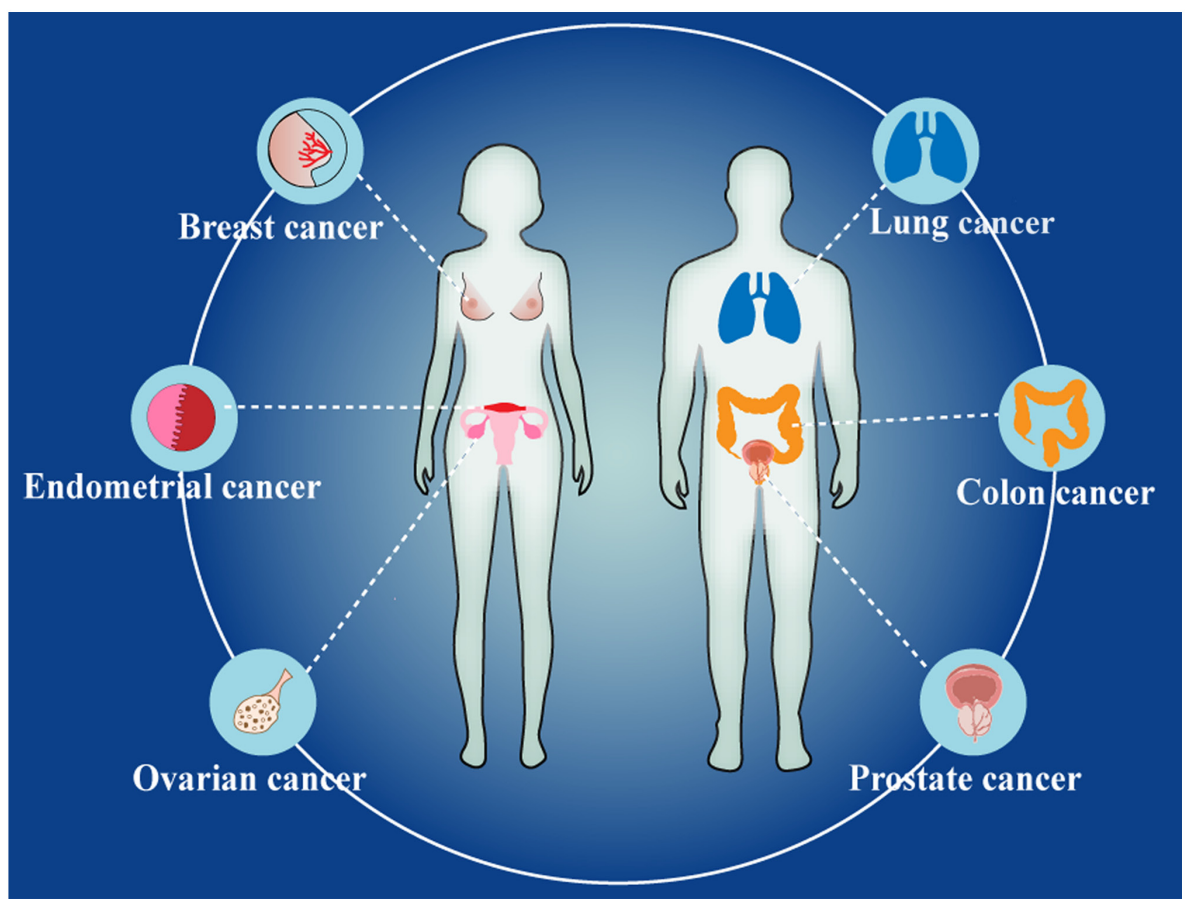

Figure 2. Types of cancer related to both ERR $\alpha$ and PPAR $\gamma$. ERR $\alpha$, estrogen receptor-associated receptor $\alpha$; PPAR $\gamma$, peroxisome proliferator-activated receptor $\gamma$.

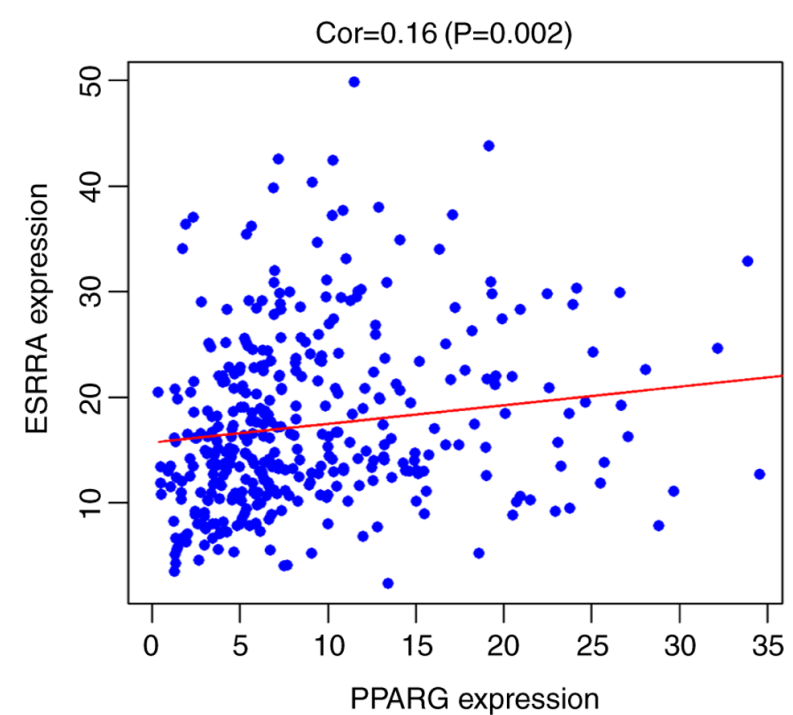

Figure 3. Pearson's correlation analysis. Pearson's correlation coefficient was performed to show the correlation between ERR $\alpha$ expression (ESRRA) and PPAR $\gamma$ expression (PPARG). ERR $\alpha$, estrogen receptor-associated receptor $\alpha$; PPAR $\gamma /$ PPARG, peroxisome proliferator-activated receptor $\gamma$; ESRRA, steroid hormone receptor ERR1.

antagonist. PPAR $\gamma$-associated diseases and related tissues are shown in Table III (96).

As aforementioned, both ERR $\alpha$ and PPAR $\gamma$ are involved in tumour development. Specifically, they were reported in studies on hormone-dependent tumours (endometrial, ovarian, breast and prostate cancer) and hormone-independent tumours (lung and colon cancer) (Fig. 2). Using R programming language (version 3.6.3; https://www.r-project.org/), based on The Cancer Genome Atlas database (https://portal.gdc.cancer. gov/), Pearson's correlation analysis was performed. It was found that ERR $\alpha$ expression was weakly positively correlated with PPAR $\gamma$ expression (correlation, $r=0.16, \mathrm{P}<0.01$; Fig. 3 ). Using bioinformatics analysis, based on the Search Tool for the Retrieval of Interacting Genes database (97), the co-expression analysis revealed that ERR $\alpha$ and PPAR $\gamma$ have a co-expression relationship (Fig. 4), suggesting that the two genes may have several similar functions. The protein-protein interaction network (http://string-db.org/cgi/input.pl) between ERR $\alpha$ and PPAR $\gamma$ showed that ERR $\alpha$ and PPAR $\gamma$ proteins interacted with nuclear receptor coactivator 1 , histone acetyltransferase p300, CREB-binding protein, leptin, adiponectin receptor protein 1 , CCAAT/enhancer-binding protein $b$ and fatty acid-binding protein adipocyte. Searching UniProt database (https://www. uniprot.org/) and GeneCards database (https://www.genecards. org/), it was found that these interacting proteins are involved in the activation of gene transcription, the modification of transcription factors and cellular energy metabolism (Fig. 5).

\section{Conclusions and perspectives}

To date, there are very few studies involving both ERR $\alpha$ and PPAR $\gamma$. A previous study demonstrated that ERR $\alpha$ knockout with small interfering RNA resulted in decreased PPAR $\gamma$ expression levels in 3T3-L1 pre-adipocytes (98). Studies have also reported that PPREs are present at the ERR $\alpha$ promoter, and PPRE was the PPAR response element (49). A previous study revealed that rosiglitazone, as a PPAR $\gamma$ agonist, could induce the expression of ERR $\alpha$ after activating the expression of PPAR $\gamma$, thus enhancing mitochondrial biogenesis and osteoclast function (49). Therefore, it can be hypothesized that there is an association between ERR $\alpha$ and PPAR $\gamma$ expression. However, further studies are required to verify and clarify this association.

In previous years, studies on ERR $\alpha$, PPAR $\gamma$ and tumorigenesis were gradually applied to clinical diagnosis and treatment. 

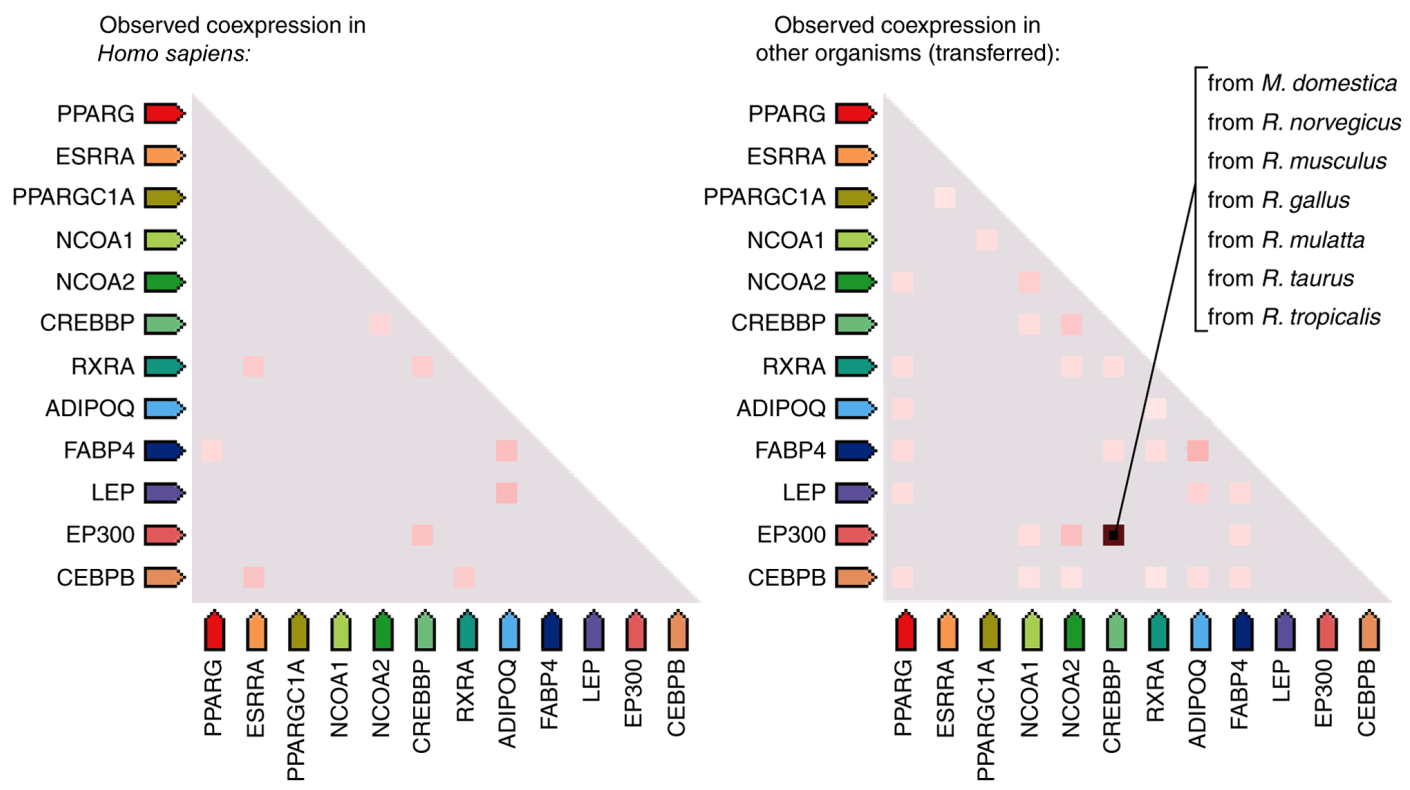

Figure 4. Co-expression network based on RNA expression patterns of ERR $\alpha$ (ESRRA) and PPAR $\gamma$ (PPARG). ERR $\alpha$, estrogen receptor-associated receptor $\alpha$; PPAR $\gamma /$ PPARG, peroxisome proliferator-activated receptor $\gamma$; ESRRA, steroid hormone receptor ERR1.

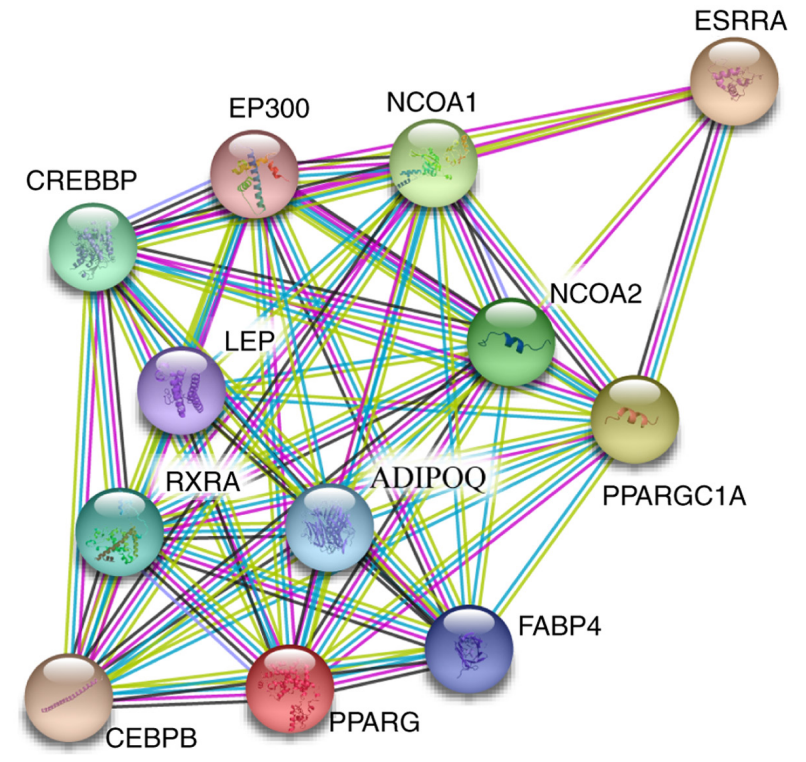

Figure 5. Protein-protein interaction network between ERR $\alpha$ and PPAR $\gamma$. The protein-protein interaction maps revealed interactome networks related to known proteome properties. ERR $\alpha$, estrogen receptor-associated receptor $\alpha$; PPAR $\gamma /$ PPARG, peroxisome proliferator-activated receptor $\gamma$; NCOA1, nuclear receptor coactivator 1; EP300, histone acetyltransferase p300; CREBBP, CREB-binding protein; LEP, leptin; ADIPOQ, adiponectin receptor protein 1; CEBPB, CCAAT/enhancer-binding protein b; FABP4, fatty acid-binding protein adipocyte; ESRRA, steroid hormone receptor ERR1; NCOA2, nuclear receptor coactivator 2; PPARGC1A, peroxisome proliferator-activated receptor $\gamma$ coactivator- $1 \alpha$; RXRA, retinoic acid receptor RXR- $\alpha$.

In diseases that have been extensively studied, such as ovarian and breast cancer, ERR $\alpha$ is generally considered to be a factor closely related to the poor prognosis of tumours, and hence is also considered to be a potential target for tumour therapy. Meanwhile, PPAR $\gamma$ expression in tumours varies, and the relationship between PPAR $\gamma$ and tumour prognosis is yet to be determined. In metabolic diseases that have been comprehensively studied, such as diabetes, PPAR $\gamma$ has become an important therapeutic target (99). ERR $\alpha$ is also closely related to numerous metabolic diseases. Currently, thiazolidinediones, as PPAR $\gamma$ agonists, have been used in the clinical treatment of metabolic syndromes, and they are expected to play an important role in the treatment of inflammation and tumours (100-102).

However, there are few reports concerning the association between ERR $\alpha$ and PPAR $\gamma$, the underlying mechanism of their interaction and their combined role in diseases. ERR $\alpha$ and PPAR $\gamma$ are related to a number of diseases, and both act as transcription factors that regulate cellular metabolic functions. Studying the relationship between ERR $\alpha$ and PPAR $\gamma$ could help to further understand the progress of certain diseases and will be useful for drug research. In addition, researches on new drugs for the ERRs have been reported (103), and thus it may be possible to develop ERR $\alpha$ and PPAR $\gamma$ dual-targeted drugs to provide further insight into the treatment of diseases.

\section{Acknowledgements}

Not applicable.

\section{Funding}

No funding was received.

\section{Availability of data and materials}

The datasets analyzed during the current study are available in the TCGA database (https://portal.gdc.cancer.gov/) and STRING: functional protein association networks (http://string-db.org/cgi/input.pl).

\section{Authors' contributions}

WYH and PMS designed the study. WYH was the major contributor in writing the manuscript. All authors read and approved the final manuscript. 


\section{Ethics approval and consent to participate}

Not applicable.

\section{Patient consent for publication}

Not applicable.

\section{Competing interests}

The authors declare that they have no competing interests.

\section{References}

1. Giguère V, Yang N, Segui P and Evans RM: Identification of a new class of steroid hormone receptors. Nature 331: 91-94, 1988

2. Wu Z, Puigserver P, Andersson U,Zhang C, Adelmant G, Mootha V, Troy A, Cinti S, Lowell B, Scarpulla RC, et al: Mechanisms controlling mitochondrial biogenesis and respiration through the thermogenic coactivator PGC-1. Cell 98: 115-124, 1999

3. Mootha VK, Handschin C, Arlow D, Xie X, St Pierre J, Sihag S, Yang W, Altshuler D, Puigserver P, Patterson N, et al: Erralpha and Gabpa/b specify PGC-1alpha-dependent oxidative phosphorylation gene expression that is altered in diabetic muscle. Proc Natl Acad Sci USA 101: 6570-6575, 2004.

4. Huss JM, Torra IP, Staels B, Giguère V and Kelly DP Estrogen-related receptor alpha directs peroxisome proliferator-activated receptor alpha signaling in the transcriptional control of energy metabolism in cardiac and skeletal muscle. Mol Cell Biol 24: 9079-9091, 2004.

5. Emmett MJ, Lim HW, Jager J, Richter HJ, Adlanmerini M, Peed LC, Briggs ER, Steger DJ, Ma T, Sims CA, et al: Histone deacetylase 3 prepares brown adipose tissue for acute thermogenic challenge. Nature 546: 544-548, 2017.

6. Dufour CR, Levasseur MP, Pham NH, Eichner LJ, Wilson BJ, Charest-Marcotte A, Duguay D, Poirier-Héon JF, Cermakian N and Giguère V: Genomic convergence among ERR $\alpha, P R O X 1$, and BMAL1 in the control of metabolic clock outputs. PLoS Genet 7: e1002143, 2011.

7. Giguère V: To ERR in the estrogen pathway. Trends Endocrinol Metab13: 220-225, 2002

8. Ranhotra HS: The estrogen-related receptor alpha: The oldest, yet an energetic orphan with robust biological functions. J Recept Signal Transduct Res 30: 193-205, 2010.

9. Issemann I and Green S: Activation of a member of the steroid hormone receptor superfamily by peroxisome proliferators. Nature 347: 645-650, 1990

10. Juge-Aubry C, Pernin A, Favez T, Burger AG, Wahli W, Meier CA and Desvergne B: DNA binding properties of peroxisome proliferator-activated receptor subtypes on various natural peroxisome proliferator response elements. Importance of the 5'-flanking region. J Biol Chem 272: 25252-25259, 1997.

11. Vamecq J and Latruffe N: Medical significance of peroxisome proliferator-activated receptors. Lancet 354: 141-148, 1999.

12. Chandra V, Huang P, Hamuro Y, Raghuram S, Wang Y, Burris TP and Rastinejad F: Structure of the intact PPAR-gamma-RXRnuclear receptor complex on DNA. Nature 456: 350-356, 2008.

13. Burns KA and Vanden Heuvel JP: Modulation of PPAR activity via phosphorylation. Biochim Biophys Acta 1771: 952-960, 2007.

14. Bookout AL, Jeong Y, Downes M, Yu RT, Evans RM and Mangelsdorf DJ: Anatomical profiling of nuclear receptor expression reveals a hierarchical transcriptional network. Cell 126 789-799, 2006

15. Bonnelye E, Vanacker JM, Dittmar T, Begue A, Desbiens X, Denhardt DT, Aubin JE, Laudet V and Fournier B: The ERR-1 orphan receptor is a transcriptional activator expressed during bone development. Mol Endocrinol 11: 905-916, 1997.

16. Heard DJ, Norby PL, Holloway J and Vissing H: Human ERRgamma, a third member of the estrogen receptor-related receptor (ERR) subfamily of orphan nuclear receptors: Tissue-specific isoforms are expressed during development and in the adult. Mol Endocrinol 14: 382-392, 2000.

17. Bonnelye E, Vanacker JM, Spruyt N, Alric S, Fournier B, Desbiens X and Laudet V: Expression of the estrogen-related receptor 1 (ERR-1) orphan receptor during mouse development. Mech Dev 65: 71-85, 1997.
18. Carnesecchi J and Vanacker JM: Estrogen-related receptors and the control of bone cell fate. Mol Cell Endocrinol 432: 37-43, 2016.

19. Likhite N, Yadav V, Milliman EJ, Sopariwala DH, Lorca S, Narayana NP, Sheth M, Reineke EL, Giguère V and Narkar V: Loss of estrogen-related receptor alpha facilitates angiogenesis in endothelial cells. Mol Cell Biol 39: 39, 2019.

20. Sun P, Sehouli J, Denkert C, Mustea A, Könsgen D, Koch I, Wei L and Lichtenegger W: Expression of estrogen receptor-related receptors, a subfamily of orphan nuclear receptors, as new tumor biomarkers in ovarian cancer cells. J Mol Med (Berl) 83: 457-467, 2005.

21. Johnston SD, Liu X, Zuo F, Eisenbraun TL, Wiley SR, Kraus RJ and Mertz JE: Estrogen-related receptor alpha 1 functionally binds as a monomer to extended half-site sequences including ones contained within estrogen-response elements. Mol Endocrinol 11: 342-352, 1997.

22. Wende AR, Huss JM, Schaeffer PJ, Giguère V and Kelly DP PGC-1alpha coactivates PDK4 gene expression via the orphan nuclear receptor ERRalpha: A mechanism for transcriptional control of muscle glucose metabolism. Mol Cell Biol 25: 10684-10694, 2005.

23. Yoon JC, Puigserver P, Chen G, Donovan J, Wu Z, Rhee J, Adelmant G, Stafford J, Kahn CR, Granner DK, et al: Control of hepatic gluconeogenesis through the transcriptional coactivator PGC-1. Nature 413: 131-138, 2001.

24. Kitamura K, Erlangga JS, Tsukamoto S, Sakamoto Y, Mabashi-Asazuma Hand Iida K: Daidzein promotes the expression of oxidative phosphorylation- and fatty acid oxidation-related genes via an estrogen-related receptor $\alpha$ pathway to decrease lipid accumulation in muscle cells. J Nutr Biochem 77: 108315, 2020.

25. Cartoni R, Léger B, Hock MB, Praz M, Crettenand A, Pich S, Ziltener JL, Luthi F, Dériaz O, Zorzano A, et al: Mitofusins 1/2 and ERRalpha expression are increased in human skeletal muscle after physical exercise. J Physiol 567: 349-358, 2005.

26. Soriano FX, Liesa M, Bach D, Chan DC, Palacín M and Zorzano A: Evidence for a mitochondrial regulatory pathway defined by peroxisome proliferator-activated receptor-gamma coactivator-1 alpha, estrogen-related receptor-alpha, and mitofusin 2. Diabetes 55: 1783-1791, 2006.

27. Rangwala SM, Li X, Lindsley L, Wang X, Shaughnessy S, Daniels TG, Szustakowski J, Nirmala NR, Wu Z and Stevenson SC: Estrogen-related receptor alpha is essential for the expression of antioxidant protection genes and mitochondrial function. Biochem Biophys Res Commun 357: 231-236, 2007.

28. Herzog B, Cardenas J, Hall RK, Villena JA, Budge PJ, Giguère V, Granner DK and Kralli A: Estrogen-related receptor alpha is a repressor of phosphoenolpyruvate carboxykinase gene transcription. J Biol Chem 281: 99-106, 2006.

29. Ranhotra HS: Estrogen-related receptor alpha and mitochondria: Tale of the titans. J Recept Signal Transduct Res 35: 386-390, 2015.

30. Vega RB and Kelly DP: A role for estrogen-related receptor alpha in the control of mitochondrial fatty acid beta-oxidation during brown adipocyte differentiation. J Biol Chem 272: 31693-31699, 1997.

31. LeBleu VS, O'Connell JT, Gonzalez Herrera KN, Wikman H, Pantel K, Haigis MC, Machado de Carvalho F, Damascena A, Domingos Chinen LT, Rocha RM, et al: PGC- $1 \alpha$ mediates mitochondrial biogenesis and oxidative phosphorylation in cancer cells to promote metastasis. Nat Cell Biol 16: 992-1003, 1001-1015, 2014.

32. Villena JA and Kralli A: ERRalpha: A metabolic function for the oldest orphan. Trends Endocrinol Metab 19: 269-276, 2008.

33. Aprile M, Ambrosio MR, D'Esposito V, Beguinot F, Formisano P, Costa V and Ciccodicola A: PPARG in human adipogenesis: Differential contribution of canonical transcripts and dominant negative isoforms. PPAR Res 2014: 537865, 2014.

34. Salgia MM, Elix CC, Pal SK and Jones JO: Different roles of peroxisome proliferator-activated receptor gamma isoforms in prostate cancer. Am J Clin Exp Urol 7: 98-109, 2019.

35. Braissant O, Foufelle F, Scotto C, Dauça M and Wahli W: Differential expression of peroxisome proliferator-activated receptors (PPARs): Tissue distribution of PPAR-alpha, -beta, and -gamma in the adult rat. Endocrinology 137: 354-366, 1996.

36. Meirhaeghe A, Fajas L, Gouilleux F, Cottel D, Helbecque N, Auwerx J and Amouyel P: A functional polymorphism in a STAT5B site of the human PPAR gamma 3 gene promoter affects height and lipid metabolism in a French population. Arterioscler Thromb Vasc Biol 23: 289-294, 2003. 
37. Martin H: Role of PPAR-gamma in inflammation. Prospects for therapeutic intervention by food components. Mutat Res 669: 1-7, 2009.

38. Tanis SP, Colca JR, Parker TT, Artman GD III, Larsen SD, McDonald WG, Gadwood RC, Kletzien RF, Zeller JB, Lee PH, et al: PPAR $\gamma$-sparing thiazolidinediones as insulin sensitizers. Design, synthesis and selection of compounds for clinical development. Bioorg Med Chem 26: 5870-5884, 2018.

39. Finch ER, Tukaramrao DB, Goodfield LL, Quickel MD, Paulson RF and Prabhu KS: Activation of PPAR $\gamma$ by endogenous prostaglandin $\mathrm{J} 2$ mediates the antileukemic effect of selenium in murine leukemia. Blood 129: 1802-1810, 2017.

40. Michalik L, Desvergne B, Dreyer C, Gavillet M, Laurini RN and Wahli W: PPAR expression and function during vertebrate development. Int J Dev Biol 46: 105-114, 2002.

41. Lapsys NM, Kriketos AD, Lim-Fraser M, Poynten AM, Lowy A, Furler SM, Chisholm DJ and Cooney GJ: Expression of genes involved in lipid metabolism correlate with peroxisome proliferator-activated receptor gamma expression in human skeletal muscle. J Clin Endocrinol Metab 85: 4293-4297, 2000.

42. Iwata M, Haruta T, Usui I, Takata Y, Takano A, Uno T, Kawahara J, Ueno E, Sasaoka T, Ishibashi O, et al: Pioglitazone ameliorates tumor necrosis factor-alpha-induced insulin resistance by a mechanism independent of adipogenic activity of peroxisome proliferator - activated receptor-gamma. Diabetes 50: 1083-1092, 2001.

43. Ricote M, Huang J, Fajas L, Li A, Welch J, Najib J, Witztum JL, Auwerx J,Palinski W and Glass CK: Expression of the peroxisome proliferator-activated receptor gamma (PPARgamma) in human atherosclerosis and regulation in macrophages by colony stimulating factors and oxidized low density lipoprotein. Proc Natl Acad Sci USA 95: 7614-7619, 1998.

44. Jiang C, Ting AT and Seed B: PPAR-gamma agonists inhibit production of monocyte inflammatory cytokines. Nature 391: 82-86, 1998

45. Yamashita H, Kawasawa YI, Shuman L, Zheng Z, Tran T, Walter V, Warrick JI, Chen G, Al-Ahmadie H, Kaag M, et al: Repression of transcription factor AP-2 alpha by PPAR $\gamma$ reveals a novel transcriptional circuit in basal-squamous bladder cancer. Oncogenesis 8: 69, 2019.

46. Fan W and Evans R: PPARs and ERRs: Molecular mediators of mitochondrial metabolism. Curr Opin Cell Biol 33: 49-54, 2015.

47. Teng CT, Li Y, Stockton P and Foley J: Fasting induces the expression of PGC-1 $\alpha$ and ERR isoforms in the outer stripe of the outer medulla (OSOM) of the mouse kidney. PLoS One 6 : e26961, 2011.

48. Angajala A, Lim S, Phillips JB, Kim JH, Yates C, You Z and Tan M: Diverse roles of mitochondria in immune responses: novel insights into immuno-metabolism. Front Immunol 9: 1605, 2018.

49. Wei W, Wang X, Yang M, Smith LC, Dechow PC, Sonoda J, Evans RM and Wan Y: PGC1beta mediates PPARgamma activation of osteoclastogenesis and rosiglitazone-induced bone loss. Cell Metab 11: 503-516, 2010.

50. Scarpulla RC: Metabolic control of mitochondrial biogenesis through the PGC-1 family regulatory network. Biochim Biophys Acta 1813: 1269-1278, 2011.

51. Xia Y, Buja LM, Scarpulla RC and McMillin JB: Electrical stimulation of neonatal cardiomyocytes results in the sequential activation of nuclear genes governing mitochondrial proliferation and differentiation. Proc Natl Acad Sci USA 94: 11399-11404, 1997.

52. Huss JM, Kopp RP and Kelly DP: Peroxisome proliferator-activated receptor coactivator-1alpha (PGC-1alpha) coactivates the cardiac-enriched nuclear receptors estrogen-related receptor-alpha and -gamma. Identification of novel leucine-rich interaction motif within PGC-1alpha. J Biol Chem 277: 40265-40274, 2002.

53. Fliegner D, Westermann D, Riad A, Schubert C, Becher E, Fielitz J, Tschöpe C and Regitz-Zagrosek V: Up-regulation of PPARgamma in myocardial infarction. Eur J Heart Fail 10: 30-38, 2008.

54. Gandhi GR, Stalin A, Balakrishna K, Ignacimuthu S, Paulraj MG and Vishal R: Insulin sensitization via partial agonism of PPAR $\gamma$ and glucose uptake through translocation and activation of GLUT4 in PI3K/p-Akt signaling pathway by embelin in type 2 diabetic rats. Biochim Biophys Acta 1830: 2243-2255, 2013.

55. Xia H, Dufour CR and Giguère V: ERR $\alpha$ as a bridge between transcription and function: Role in liver metabolism and disease. Front Endocrinol (Lausanne) 10: 206, 2019.
56. Mootha VK, Lindgren CM, Eriksson KF, Subramanian A Sihag S, Lehar J, Puigserver P, Carlsson E, Ridderstråle M, Laurila E, et al: PGC-1alpha-responsive genes involved in oxidative phosphorylation are coordinately downregulated in human diabetes. Nat Genet 34: 267-273, 2003.

57. Schreiber SN, Emter R, Hock MB, Knutti D, Cardenas J, Podvinec M, Oakeley EJ and Kralli A: The estrogen-related receptor alpha (ERRalpha) functions in PPARgamma coactivator 1alpha (PGC-1alpha)-induced mitochondrial biogenesis. Proc Natl Acad Sci USA 101: 6472-6477, 2004.

58. Rutanen J, Yaluri N, Modi S, Pihlajamäki J, Vänttinen M, Itkonen P, Kainulainen S, Yamamoto H, Lagouge M, Sinclair DA, et al: SIRT1 mRNA expression may be associated with energy expenditure and insulin sensitivity. Diabetes 59: 829-835, 2010.

59. B'chir W, Dufour CR, Ouellet C, Yan M, Tam IS, Andrzejewski S, Xia H, Nabata K, St-Pierre J and Giguère V: Divergent role of estrogen-related receptor $\alpha$ in lipid- and fasting-induced hepatic steatosis in mice. Endocrinology 159: 2153-2164, 2018.

60. Chaveroux C, Eichner LJ, Dufour CR, Shatnawi A, Khoutorsky A, Bourque G, Sonenberg N and Giguère V: Molecular and genetic crosstalks between mTOR and ERR $\alpha$ are key determinants of rapamycin-induced nonalcoholic fatty liver. Cell Metab 17: 586-598, 2013

61. Sakamoto T, Matsuura TR, Wan S, Ryba DM, Kim JU, Won KJ, Lai L, Petucci C, Petrenko N, Musunuru K, et al: A Critical Role for Estrogen-Related Receptor Signaling in Cardiac Maturation. Circ Res 126: 1685-1702, 2020.

62. Mitra MS, Schilling JD, Wang X, Jay PY, Huss JM, Su X and Finck BN: Cardiaclipin 1 expression is regulated by the peroxisome proliferator activated receptor $\gamma$ coactivator $1 \alpha /$ estrogen related receptor axis. J Mol Cell Cardiol 51: 120-128, 2011.

63. Gomez-Arroyo J, Mizuno S, Szczepanek K, Van Tassell B, Natarajan R, dos Remedios CG, Drake JI, Farkas L, Kraskauskas D, Wijesinghe DS, et al: Metabolic gene remodeling and mitochondrial dysfunction in failing right ventricular hypertrophy secondary to pulmonary arterial hypertension. Circ Heart Fail 6: 136-144, 2013.

64. Watson PA, Birdsey N, Huggins GS, Svensson E, Heppe D and Knaub L: Cardiac-specific overexpression of dominant-negative CREB leads to increased mortality and mitochondrial dysfunction in female mice. Am J Physiol Heart Circ Physiol 299: H2056-H2068, 2010.

65. Sun PM, Gao M, Wei LH, Mustea A, Wang JL, Könsgen D, Lichtenegger W and Sehouli J: An estrogen receptor alpha-dependent regulation of estrogen receptor-related receptor alpha in the proliferation of endometrial carcinoma cells. Int J Gynecol Cancer 16 (Suppl 2): 564-568, 2006.

66. Stein RA, Gaillard S and McDonnell DP: Estrogen-related receptor alpha induces the expression of vascular endothelial growth factor in breast cancer cells. J Steroid Biochem Mol Biol 114: 106-112, 2009.

67. Cheung CP, Yu S, Wong KB, Chan LW, Lai FM, Wang X, Suetsugi M, Chen S and Chan FL: Expression and functional study of estrogen receptor-related receptors in human prostatic cells and tissues. J Clin Endocrinol Metab 90: 1830-1844, 2005.

68. Fujimoto J and Sato E: Clinical implication of estrogen-related receptor (ERR) expression in uterine endometrial cancers. J Steroid Biochem Mol Biol 116: 71-75, 2009.

69. Kraus RJ, Ariazi EA, Farrell ML and Mertz JE: Estrogen-related receptor alpha 1 actively antagonizes estrogen receptor-regulated transcription in MCF-7 mammary cells. J Biol Chem 277: 24826-24834, 2002.

70. Ma JH, Qi J, Lin SQ, Zhang CY, Liu FY, Xie WD and Li X: STAT3 targets ERR- $\alpha$ to promote epithelial-mesenchymal transition, migration, and invasion in triple-negative breast cancer cells. Mol Cancer Res 17: 2184-2195, 2019.

71. Fujimura T, Takahashi S, Urano T, Kumagai J, Ogushi T, Horie-Inoue K, Ouchi Y, Kitamura T, Muramatsu M and Inoue S: Increased expression of estrogen-related receptor alpha (ERRalpha) is a negative prognostic predictor in human prostate cancer. Int J Cancer 120: 2325-2330, 2007.

72. Hong F, Pan S, Guo Y, Xu P and Zhai Y: PPARs as nuclear receptors for nutrient and energy metabolism. Molecules 24: 2545, 2019.

73. Fougerat A, Montagner A, Loiseau N, Guillou H and Wahli W: Peroxisome proliferator-activated receptors and their novel ligands as candidates for the treatment of non-alcoholic fatty liver disease. Cells 9: 9, 2020.

74. Shi Y, Zou Y, Shen Z, Xiong Y, Zhang W, Liu C and Chen S: Trace elements, PPARs, and metabolic syndrome. Int J Mol Sci 21: 21,2020 . 
75. Thangavel N, Al Bratty M, Akhtar Javed S, Ahsan W and Alhazmi HA: Targeting peroxisome proliferator-activated receptors using thiazolidinediones: Strategy for design of novel antidiabetic drugs. Int J Med Chem 2017: 1069718, 2017.

76. Ribon V,JohnsonJH,CampHS and Saltiel AR: Thiazolidinediones and insulin resistance: Peroxisome proliferatoractivated receptor gamma activation stimulates expression of the CAP gene. Proc Natl Acad Sci USA 95: 14751-14756, 1998.

77. Schinner S, Dellas C, Schroder M, Heinlein CA, Chang C, Fischer J and Knepel W: Repression of glucagon gene transcription by peroxisome proliferator-activated receptor gamma through inhibition of Pax6 transcriptional activity. J Biol Chem 277: 1941-1948, 2002.

78. Tontonoz P, Nagy L, Alvarez JG, Thomazy VA and Evans RM: PPARgamma promotes monocyte/macrophage differentiation and uptake of oxidized LDL. Cell 93: 241-252, 1998.

79. Maréchal L, Laviolette M, Rodrigue-Way A, Sow B, Brochu M, Caron $\mathrm{V}$ and Tremblay A: The CD36-PPAR $\gamma$ pathway in metabolic disorders. Int J Mol Sci 19: 19, 2018

80. Chawla A, Barak Y, Nagy L, Liao D, Tontonoz P and Evans RM: PPAR-gamma dependent and independent effects on macrophage-gene expression in lipid metabolism and inflammation. Nat Med 7: 48-52, 2001.

81. Chandra M, Miriyala S and Panchatcharam M: PPAR $\gamma$ and its role in cardiovascular diseases. PPAR Res 2017: 6404638, 2017.

82. Fukunaga $Y$, Itoh $H$, Doi $K$, Tanaka T, Yamashita J, Chun TH, Inoue M, Masatsugu K, Sawada N, Saito T, et al: Thiazolidinediones, peroxisome proliferator-activated receptor gamma agonists, regulate endothelial cell growth and secretion of vasoactive peptides. Atherosclerosis 158: 113-119, 2001.

83. Chang JS and Ha K: A truncated PPAR gamma 2 localizes to mitochondria and regulates mitochondrial respiration in brown adipocytes. PLoS One 13: e0195007, 2018.

84. Dong JT: Anticancer activities of PPAR $\gamma$ in breast cancer are context-dependent. Am J Pathol 182: 1972-1975, 2013.

85. Lin SJ, Lin CY, Yang DR, Izumi K, Yan E, Niu X, Chang HC, Miyamoto H, Wang N, Li G, et al: The differential effects of anti-diabetic thiazolidinedione on prostate cancer progression are linked to the TR4 nuclear receptor expression status. Neoplasia 17: 339-347, 2015.

86. Lakshmi SP, Reddy AT, Banno A and Reddy RC: PPAR agonists for the prevention and treatment of lung cancer. PPAR Res 2017: 8252796,2017

87. Yousefnia S, Momenzadeh S, Seyed Forootan F, Ghaedi K and Nasr Esfahani MH: The influence of peroxisome proliferator-activated receptor $\gamma(\mathrm{PPAR} \gamma)$ ligands on cancer cell tumorigenicity. Gene 649: 14-22, 2018.

88. Holland CM, Saidi SA, Evans AL, Sharkey AM, Latimer JA, Crawford RA, Charnock-Jones DS, Print CG and Smith SK Transcriptome analysis of endometrial cancer identifies peroxisome proliferator-activated receptors as potential therapeutic targets. Mol Cancer Ther 3: 993-1001, 2004.

89. Zhang GY, Ahmed N, Riley C, Oliva K, Barker G, Quinn MA and Rice GE: Enhanced expression of peroxisome proliferator-activated receptor gamma in epithelial ovarian carcinoma. Br J Cancer 92: 113-119, 2005.
90. Davidson B, Hadar R, Stavnes HT, Trope' CG and Reich R: Expression of the peroxisome proliferator-activated receptors-alpha,-beta, and -gamma in ovarian carcinoma effusions is associated with poor chemoresponse and shorter survival. Hum Pathol 40: 705-713, 2009.

91. Luo S, Wang J, Ma Y, Yao Z and Pan H: PPAR $\gamma$ inhibits ovarian cancer cells proliferation through upregulation of miR-125b. Biochem Biophys Res Commun 462: 85-90, 2015.

92. Ogino S, Shima K, Baba Y, Nosho K, Irahara N, Kure S, Chen L, Toyoda S, Kirkner GJ, Wang YL, et al: Colorectal cancer expression of peroxisome proliferator-activated receptor gamma (PPARG, PPARgamma) is associated with good prognosis. Gastroenterology 136: 1242-1250, 2009.

93. Reka AK,KurapatiH,Narala VR,BommerG,Chen J,Standiford TJ and Keshamouni VG: Peroxisome proliferator-activated receptor-gamma activation inhibits tumor metastasis by antagonizing Smad3-mediated epithelial-mesenchymal transition. Mol Cancer Ther 9: 3221-3232, 2010.

94. Dong YW, Wang XP and Wu K: Suppression of pancreatic carcinoma growth by activating peroxisome proliferator-activated receptor gamma involves angiogenesis inhibition. World J Gastroenterol 15: 441-448, 2009.

95. He Q, Pang R, Song X, Chen J, Chen H, Chen B, Hu P and Chen $\mathrm{M}$ : Rosiglitazone suppresses the growth and invasiveness of SGC-7901 gastric cancer cells and angiogenesis in vitro via PPARgamma dependent and independent mechanisms. PPAR Res 2008: 649808, 2008.

96. Wang YX: PPARs: Diverse regulators in energy metabolism and metabolic diseases. Cell Res 20: 124-137, 2010

97. Szklarczyk D, Gable AL, Lyon D, Junge A, Wyder S, Huerta-Cepas J, Simonovic M, Doncheva NT, Morris JH, Bork P, et al: STRING v11: Protein-protein association networks with increased coverage, supporting functional discovery in genome-wide experimental datasets. Nucleic Acids Res 47: D607-D613, 2019.

98. Ijichi N, Ikeda K, Horie-Inoue K, Yagi K, Okazaki Y and Inoue S: Estrogen-related receptor alpha modulates the expression of adipogenesis-related genes during adipocyte differentiation. Biochem Biophys Res Commun 358: 813-818, 2007.

99. Prabhu DS and Rajeswari VD: PPAR-Gamma as putative gene target involved in Butein mediated anti-diabetic effect. Mol Biol Rep 47: 5273-5283, 2020.

100. Lebovitz HE: Thiazolidinediones: The forgotten diabetes medications. Curr Diab Rep 19: 151, 2019.

101. Heneka MT, Sastre M, Dumitrescu-Ozimek L, Hanke A Dewachter I, Kuiperi C, O'Banion K, Klockgether T, Van Leuven F and Landreth GE: Acute treatment with the PPARgamma agonist pioglitazone and ibuprofen reduces glial inflammation and Abetal-42 levels in APPV717I transgenic mice. Brain 128: $1442-1453,2005$

102. WuertzBR,DarrahL,Wudel Jand OndreyFG: Thiazolidinediones abrogate cervical cancer growth. Exp Cell Res 353: 63-71, 2017.

103. Sanghvi M, Moaddel R, Frazier C, Gandhari M and Wainer IW: Abstract 5500: Biochromatography for the screening of new drugs for the estrogen related receptors. Cancer Res 70: 5500, 2010 . 